\title{
Research on the Cultivation of Tianjin MICE Tourism Industry Cluster*
}

\author{
Xiaoyan Qiao \\ Tianjin Sino-German University of Applied Sciences \\ Tianjin, China 300350
}

\begin{abstract}
MICE industry and tourism industry play an important role of "promoting growth and adjusting structure" in the economic development of China relying on its strong economic driving role. MICE industry and tourism gradually show a convergence trend, which can effectively make up for the shortcomings of non-core business of single industry and promote the efficiency of the two major industries to improve quality. Cultivating MICE tourism industry cluster has become the inevitable trend of Tianjin's economic development. This paper analyzes the favorable conditions and existing problems of Tianjin MICE tourism industry cluster, and puts forward the cultivation strategy of Tianjin MICE tourism industry cluster from four aspects.
\end{abstract}

Keywords-Tianjin; MICE tourism; industrial clusters; cultivation

\section{INTRODUCTION}

As an important part of the economic belt around Bohai Sea, Tianjin is the third growth pole of the national economy, especially the regional economy. As a "strategic emerging industry" in the development of Tianjin's urban economy, MICE has been highly valued by the Tianjin government because of its powerful economic impetus. In 2017, The General Office of the Tianjin People's Government issued the Opinion on the Further Promotion of Reform and Development of MICE Industry, which pointed out that it is necessary to take the convention and exhibition industry as the leading industry, to build industrial clusters supported by advanced manufacturing, scientific and technological information, culture and education, transportation and logistics, financial services and commercial tourism, and to take advertising, planning, design, printing, leasing, construction and on-site service as supporting services. This fully embodies the thought of "big MICE" of Tianjin government. Under the background of "big MICE", it is a general trend to speed up the deep integration of MICE industry and related industries and to construct the industrial cluster of "big MICE".

As a "strategic pillar industry" of the national economy, tourism plays an active role in industry pulling function, which greatly promotes the sustained growth of business logistics, accommodation and catering, transportation, and entertainment and other services? In recent years, tourism contributes more and more to Tianjin's economy and employment, as detailed in "Table I". Tianjin is changing from an industrial city to a commercial city. Tourism as the driving industry of the economic transformation and upgrading under the new normal condition, is playing a more and more important role in "expanding domestic demand, stabilizing increase, increasing employment, reducing poverty and benefiting the people's livelihood", and will certainly become an important carrier and boosting engine for Tianjin's economic transformation and upgrading and the development of its service industry. Tianjin municipal government attaches great importance to the development of tourism from the overall economic and social development strategy of the city, puts tourism on the more important agenda, and puts forward a series of policies to promote the development of tourism.

TABLE I. MAIN ECONOMIC INDICATORS OF TIANJIN TOURISM DEVELOPMENT IN RECENT YEARS

\begin{tabular}{|c|c|c|c|c|c|c|}
\hline \multicolumn{2}{|c|}{ Item $\quad$ year } & 2005 & $\begin{array}{c}\text { average annual } \\
\text { growth }\end{array}$ & 2010 & $\begin{array}{l}\text { average annual } \\
\text { growth }\end{array}$ & 2015 \\
\hline \multirow{2}{*}{$\begin{array}{l}\text { inbound } \\
\text { visitor }\end{array}$} & $\begin{array}{l}\text { tourist number } \\
\text { ( } 10000 \text { people })\end{array}$ & 74.01 & $17.5 \%$ & 166.07 & $14.4 \%$ & 326.01 \\
\hline & Income (\$100 million) & 5.09 & $22.8 \%$ & 14.2 & $18.3 \%$ & 32.98 \\
\hline \multirow{2}{*}{$\begin{array}{l}\text { domestic } \\
\text { visitor }\end{array}$} & $\begin{array}{l}\text { tourist number } \\
(10000 \text { people })\end{array}$ & 5013.4 & $12.9 \%$ & 9206.5 & $13 \%$ & 17000 \\
\hline & Income (\$100 million) & 541.98 & $16.3 \%$ & 1151.9 & $17.6 \%$ & 2588 \\
\hline \multicolumn{2}{|c|}{ Total number (10000 people) } & 5087.41 & $13 \%$ & 9372.57 & $13 \%$ & 17400 \\
\hline \multicolumn{2}{|c|}{ Total income (\$100 million) } & 584.23 & $16.4 \%$ & 1248.4 & $14.7 \%$ & 2794.25 \\
\hline
\end{tabular}

*Fund Project: Research on the Training Mode of Exhibition Talents in Higher Vocational Colleges from the Perspective of "Grand

Exhibition", a Key Project at School Level in Tianjin Sino-German University of Applied Sciences.
MICE industry and tourism industry have a natural industrial correlation. The two appear the integration trend in the industry, and derive a new industrial system of MICE 
tourism. The integration and development of MICE industry can make up for the shortcomings of non-core business of single industry, promote the efficiency and quality of two major industries, and form more significant economic benefits. It has become the common strategic choice of government, industry and enterprise to integrate the MICE industry and tourism, and cultivating MICE industry cluster has become the inevitable trend of urban economic development. "Thirteenth Five-Year Plan" of Tianjin Tourism Development points out that it is necessary to strengthen coordination and optimize the development environment of convention and exhibition industry by relying on such infrastructure as Meijiang International Convention and Exhibition Center, Binhai International Convention and Exhibition Center, and National Convention and Exhibition Center, strengthen publicity and promotion, make use of the momentum to hold investment promotion activities, and vigorously develop business exhibition tourism by holding the Davos Forum, China Tourism Expo, Tianjin Investment and Trade Fair, and China Mining, and so on as the lead."

\section{THE CONNOTATION OF MICE TOURISM INDUSTRY CluUSTER}

Clusters are geographic clusters of interrelated companies, specialized suppliers, service providers and related industries, as well as governments and other relevant institutions (such as universities, and trade associations, etc.) within specific regions that compete and cooperate with each other. Industrial convergence refers to the process of dynamic development of different industries or different products in the same industry penetrating each other crossing each other finally melting into one body and gradually forming new industries.

MICE tourism industry cluster is an industrial cluster composed of MICE industry, tourism industry and upstream and downstream industry by taking MICE as the core in the process of providing services for MICE participants. On the one hand, exhibitors and professional audience become the important support for the development of high-end tourism market. The large-scale convention and exhibition activities gradually become the tourist attraction, which injected vigor into the tourism market, and the business tourism, and incentive tourism and so on are the high profit plate of the tourism industry. On the other hand, with the rapid development of China's tourism industry, industry strength is growing, and tourism industry expo has gradually become an important segment of the exhibition business. In addition, with the increasing diversification of consumer demand, MICE industry and tourism are becoming more and more complementary. It is an inevitable choice for the two industries to cultivate MICE tourism industry cluster in the new period.
III. THE FAVORABLE CONDITIONS AND EXISTING PROBLEMS OF CULTIVATING THE MICE TOURISM INDUSTRY CLUSTER IN TIANJIN

\section{A. Favorable Conditions for the Cultivation of MICE Tourism Clusters in Tianjin}

1) Good economic foundations: A study by the International Exhibition Federation (UFI) shows that If a country, city or region has a relatively complete infrastructure, per capita income above the world level, the contribution of service industry income to GDP exceeding manufacturing industry and the total proportion by over $50 \%$, and strong strength of industry association, MICE tourism will also grow rapidly in this country, city or region and play an active role. In 2017, Gross Domestic Product (GDP) of Tianjin was 1859.538 billion yuan, and the three industrial structures were 1.2: 40.8: 58.0, which accorded with the economic conditions for the development of MICE tourism.

2) Superior geographical conditions: Tianjin adjoins the capital Beijing. As the railway throat from Beijing to the northeast and East China and ocean shipping port, it is called the "communications hub of river and sea" and "Jifu gateway". Under the background of the coordinated development of Beijing, Tianjin and Hebei, Tianjin has unique advantages in geography and political location. As the core city of the Bohai Economic Circle, Tianjin has developed rapidly in the fields of producer services, finance, modern manufacturing and high-tech industries, brought together a large number of enterprise headquarters, financial institutions and scientific research institutes, thus providing convenient conditions for the development of MICE industry.

3) Improved MICE tourism facilities: At present, there are four exhibition venues including Tianjin National Convention and Exhibition Center (under construction), Tianjin Meijiang Convention and Exhibition Center, Tianjin Binhai International Convention and Exhibition Center, and Tianjin International Exhibition Center in Tianjin in "Table II". Among them, Tianjin National Convention and Exhibition Center, located in the middle reaches of the Haihe River in Tianjin, is the national convention and exhibition center jointly built by the Ministry of Commerce and Tianjin, and is the third largest international convention and exhibition center following Shanghai and Guangzhou. With a total area of 1.2 million square meters and a net exhibition area of 400,000 square meters, the newly-built Convention and Exhibition Center ranks among the largest convention and Exhibition centers in the world, and is also the largest convention and Exhibition center in eastern China. 
TABLE II. FACILITIES OF EXHIBITION HALL IN TIANJIN

\begin{tabular}{|c|c|c|c|c|}
\hline name of exhibition hall & Place & $\begin{array}{c}\text { Building area } \\
\text { (square kilometres) }\end{array}$ & $\begin{array}{c}\text { Exhibition area } \\
\text { (square kilometre) }\end{array}$ & $\begin{array}{c}\text { Meeting area (square } \\
\text { kilometre) }\end{array}$ \\
\hline $\begin{array}{l}\text { Tianjin National Convention and Exhibition } \\
\text { Center }\end{array}$ & $\begin{array}{l}\text { Jinnan } \\
\text { District }\end{array}$ & 1.2 million & 400 thousand & unknown \\
\hline $\begin{array}{l}\text { Tianjin Meijiang Convention and Exhibition } \\
\text { Center }\end{array}$ & $\begin{array}{l}\text { Xiqing } \\
\text { District }\end{array}$ & 100 thousand & 87 thousand & 8000 \\
\hline Tianjin Binhai international exhibition center & $\begin{array}{ll}\text { Binhai } & \text { New } \\
\text { District } & \\
\end{array}$ & 120 thousand & 60 thousand & 7500 \\
\hline Tianjin international exhibition center & Hexi District & 46 thousand & 35 thousand & unknown \\
\hline
\end{tabular}

At present, there are 592 travel agencies in Tianjin, of which 57 are outbound travel agencies, 430 are inbound travel agencies and 105 are outbound travel agencies. Tianjin has $108 \mathrm{~A}$-class scenic spots, including 2 5A-class scenic spots, 31 4A-class scenic spots, 52 3A-class scenic spots and $232 \mathrm{~A}$-class scenic spots. Tianjin has 87 star hotels, 15 fivestar hotels, 35 four-star hotels, 32 three-star hotels and 5 twostar hotels. Details can be seen in "Table III".

TABLE III. TOURISM FACILITIES IN TIANJIN

\begin{tabular}{|l|l|l|}
\hline \multicolumn{2}{|c|}{ types of tourism facilities } & quantity \\
\hline \multirow{3}{*}{$\begin{array}{l}\text { travel } \\
\text { agency }\end{array}$} & Outbound travel agency & 57 \\
\cline { 2 - 3 } & domestic inbound travel agency & 430 \\
\hline A-level scenic spot & 105 \\
\hline \multicolumn{2}{|c|}{ star grade hotel } & 108 \\
\hline \multicolumn{2}{|c}{${ }^{\mathrm{b} .}$ Information from Tianjin Tourism Government Network }
\end{tabular}

\section{B. Problems in the Cultivation of MICE Tourism Industrial Clusters in Tianjin}

1) Lack of integrated management and corporate planning: At present, the Tianjin Commerce Commission is in charge of the development of the convention and exhibition industry, while the Tianjin Tourism Administration conducts a unified management and planning of the tourism industry. From the perspective of tourism industry or convention and exhibition industry, Tianjin has established a relatively perfect management system and the competent agencies of the two industries have also issued a series of policies to promote the development of the industry. However, Tianjin MICE industry and tourism are still in a state of "divide and rule". Tianjin has not yet established a unified MICE tourism agency and lacks unified management and overall planning, which is not conducive to the cultivation of MICE tourism industry cluster in Tianjin.

2) MICE tourism industry chain is short and the overall linkage effect is low: Tianjin MICE tourism industry has not yet formed the interdependent division of labor and cooperation system. The related enterprises, especially the MICE enterprises, exhibition venues, tourism scenic spots, hotels, travel agencies and so on, have not formed industrial clusters, and the overall linkage effect is low.

3) Lack of support of strong policy: From the situation of the policy formulation, Tianjin Convention and Exhibition Policy has not been paid enough attention to. At present, there are only "Tianjin Promotion Association
Exhibition Development Measures" issued in 2011 and "Tianjin People's Government General Office on Further Promotion Association Exhibition Reform and Development Opinion" promulgated in 2017. In 2011, Tianjin Binhai New Area promulgated the Interim Measures on the Management of Special Funds for Promoting Economic Development in Binhai New Area, which includes special funds for the exhibition industry, but the document expired on August 31, 2016.

In recent years, the Municipal Party Committee and the Municipal Government attach great importance to the development of tourism. In 2004, they upgraded the deputy bureau unit of tourism office to the bureau-level unit of tourism bureau, and the funds for tourism development increased from 15 million yuan to 120 million yuan per year. From the perspective of the formulation of tourism policy, there are the "13th Five-Year Plan for the Development of Tourism in Tianjin", the "Notice of the Tianjin People's Government on Accelerating the Development of Tourism" issued in 2000, and the "Implementation Opinion on Promoting the Integration of Culture and Tourism" issued in 2014.

\section{FOSTERING STRATEGY OF TIANJIN MICE TOURISM INDUSTRY CLUSTER}

\section{A. Incorporating the Cultivation of MICE Tourism Industry Cluster into Tianjin's Development Strategy}

Tianjin government should incorporate the cultivation of MICE tourism industry clusters into its urban development strategy, make the development plan of the MICE tourism industry cluster, follow the inherent law of the integration and development of the tourism industry, make rationally arrangement and positioning by combining the advantages and characteristics of the city economy and enterprises, scientifically planning to coordinate the development of the MICE tourism industry cluster, and promote the healthy and rapid development of the MICE tourism industry cluster.

\section{B. Establishing a Unified and Coordinated MICE Tourism Management Mechanism}

The cultivation of MICE tourism industry cluster must be based on the coordinated development of MICE industry and tourism, which requires the establishment of a unified and coordinated management system. First of all, drawing on the successful experience of the Boston Conference and Tourism Bureau, the San Francisco Conference and Tourism Bureau, we can establish the Tianjin MICE Tourism Development 
Committee. Secondly, on the basis of the existing tourism industry associations and exhibition industry associations, the MICE tourism industry associations should be set up, and the relaxed admittance system should be set up to allow the MICE tourism-related enterprises to join, so as to promote the enterprise resource sharing, information exchange, business cooperation and mutual benefit among different industries.

\section{Promoting the Integration of Industrial Sector of Exhibition and Tourism}

First of all, drawing on the successful experience of Chengdu MICE Tourism Group, Tianjin MICE Tourism Group can be built, which is a a large enterprise group integrating conferences, exhibitions, tourism, hotels, scenic spots management, real estate development, and property management and other industries. Secondly, on the basis of mutual benefit and win-win, convention and exhibition tourism economic association can be constructed by taking information flow and passenger flow as the link and national convention and exhibition center (Tianjin), Tianjin Meijiang convention and exhibition center, Tianjin Binhai international convention and exhibition center, convention and exhibition company, large-scale event office, travel agency, high-star hotel as the main members.

\section{Guiding MICE Tourism-related Enterprises and Institutions to Gather in Space}

Relevant departments of Tianjin government guide MICE tourism-related enterprises to gather in space through urban planning and economic policies. First, we should strengthen the construction of supporting facilities for MICE tourism, promulgate preferential policies to promote the location and development of MICE tourism-related enterprises and intermediary services around the National Convention and Exhibition Center (Tianjin). Second, the leading enterprises of MICE tourism provide information, capital, market network and other support for MICE tourism related enterprises through platform construction, and promote these enterprises to carry out spatial distribution around the MICE tourism core enterprises. The third is to support colleges and universities to develop the training of MICE tourism talents, to establish corresponding MICE tourism research institutions, and to cooperate with MICE tourism enterprises.

\section{CONCLUSION}

Tianjin is in a crucial period of transformation from an industrial city to a commercial city. MICE tourism will certainly become an important carrier and booster engine for the upgrading of Tianjin's economy and the development of its service industry. It is a general trend to cultivate MICE tourism industry cluster. Tianjin has a good economic base, superior location conditions, and perfect MICE tourism facilities. At the same time, Tianjin MICE tourism lack unified management and overall planning and strong policy support and the overall linkage effect is low. To sum up, this paper puts forward the strategies to cultivate the MICE tourism industry cluster in Tianjin: to bring the MICE tourism industry cluster into the development strategy of Tianjin, to establish a unified and coordinated MICE tourism management mechanism, to promote the integration of MICE and tourism industry sectors, and to guide the MICE tourism-related enterprises and institutions to gather in space.

\section{REFERENCES}

[1] Poter, E.M.2000 Location, competition and economic development: local cluster in global economy, Economic Development Quarterly $14: 15-20$.

[2] Li Wuwei, Wang Zhen. Frontier Issues of Industrial Development in China's [M]. Shanghai: Shanghai People's Publishing House, 2003. 厉 无畏, 王振. 中国产业发展前沿问题 [M]. 上海: 上海人民出版 社, 2003

[3] Cheng Jianlin, Ai Chunling. MICE economic development, MICE urban competitiveness and urban function promotion $[\mathrm{J}]$. City Planning Review, 2008.32 (10). 程建林, 艾春玲. 会展经济发展、会 展城市竞争力与城市功能提升 [J]. 城市规划, 2008. 32 (10)

[4] Yu Shihong. Analysis of Factors Influencing the Competitiveness of Urban MICE Industry Based on Diamond Model [J]. Liaoning Economy, 2008 (4): 58-58. 于世宏. 基于钻石模型的城市会展业竞 争力的影响因素分析 [J]. 辽宁经济, 2008 (4):58-58.

[5] Guo Luan. The Cultivation of Urban MICE Tourism Industrial Clusters under the Trend of Industrial Convergence: A Case Study of Nanning City [J]. Journal of Guangxi University(Philosophy and Social Science), 2011, 33 (4). 郭峦. 产业融合趋势下城市会展旅游 产业集群的培育——以南宁市为例 $[\mathrm{J}]$. 广西大学学报（哲学社会 科学版) , 2011, 33(4).

[6] Xue Jingyi. Research on the Development of MICE Tourism in Guangxi [D]. Guangxi Normal University, 2014. 薛靖懿. 广西会展 旅游发展研究 $[D]$. 广西师范大学, 2014.

[7] Zhang Le, Zhang Ning. Research on the Cultivation Strategies of MICE Tourism Clusters in Small and Medium-sized Cities [J]. Chinese and Foreign Entrepreneurs, 2015 (10). 张乐, 张宁. 中小城市 会展旅游产业集群培育策略研究 [J]. 中外企业家, 2015（10）。

[8] Tianjin Tourism Bureau. "13th Five-Year Plan" of Tianjin Tourism Development [EB/OL] Tianjin Tourism Government Network, 20184-18. 天津旅游局. 天津旅游业发展 “十三五” 规划 [EB/OL] 天津 旅游政务网, 2018-4-18. 